\title{
Haematological and Histopathological Effects of Mosquito Coil Smoke on Kidney-An Experimental study on Albino Rat.
}

\author{
Masooma Syed', Sheikh Tousia ${ }^{2}$, Kamaldeep Singh Balowria ${ }^{3}$, Nusrat Jabeen ${ }^{4}$, Nafis Ahmad Faruqi ${ }^{5}$, Arshi Beg ${ }^{6}$ \\ ${ }^{1}$ Senior Resident, Department of Anatomy, J.N.M.C, A.M.U, Aligarh, ${ }^{2}$ MD, Department of Anatomy, ${ }^{3}$ MD, Department of Anatomy, Medical officer.PHC, \\ Bhalla Doda, ${ }^{4}$ Associate Professor, Post graduate Department of Anatomy, GMC Jammu, ${ }^{5}$ Professor, Department of Anatomy, Department Of \\ Anatomy,J.N.M.C, A.M.U,Aligarh, ${ }^{6}$ Resident, Department of Oncopathology, Tata Memorial Hospital, Mumbai.
}

\section{Abstract}

Introduction: Mosquitoes have long been identified as the main vectors of many human and animal diseases like West Nile fever, malaria, dengue, etc. Mosquito coils are the most preferred mosquito repellent products used especially in low-income communities, due to cheap price. The most common active ingredients in mosquito coils pyrethroids, are known to cause nephrotoxicity and,haematoxicity. However substantial data is lacking on the effects of mosquito coils containing d-trans allethrin. Subjects and Methods: In this study we report the histological and haematological effects of smoke from such coil on albino rat (Wistar). The study was performed on Thirty albino rats divided into five groups (A, B, C, D, E) of six animals each. Control group A we left unexposed to coil smoke while rest (B-E) were exposed for 4, 6,8,10 weeks respectively. Results: We observed a statistically significant increase in the levels of serum urea and creatinine in experimental groups C, D and E. Levels of serum sodium and potassium remained unaffected in the experimental animals. Histopathological studies on kidneys revealed generalised degenerative changes proportional to quantity of coil smoke exposure. Conclusion: General human masses should be made aware about such possible hazards and adequate measures should be taken to ensure minimal exposure to coil smoke during domestic use.

Keywords: Mosquito coil, Histopathology, Haematology, Rat, Experimental study.

Corresponding Author: Masooma Syed, Senior Resident, Department of Anatomy, Jawaharlal Nehru Medical College, Aligarh Muslim University, Aligarh, 202002, India.

Received: March 2019

Accepted: March 2019

\section{Introduction}

Mosquitoes have long been identified as the main vectors of many human and animal diseases like West Nile fever, malaria, dengue, etc. The latest estimates from WHO put new cases of malaria worldwide at 214 million in the year 2015 with an estimated 4,38,000 deaths. According to NVBDCP, there were around 0.67 million cases of malaria, with 84 million related deaths in the year 2017 till the month of September in India. ${ }^{[1]}$

Mosquito coils are the most preferred anti-mosquito products in low-income communities because they are cheap and readily available and are burned indoors as a common practice in many households of South America, Africa and Asian countries like India. The most common active ingredients in mosquito coils, which comprise about 0.3 $0.4 \%$ of the coil mass are pyrethroids that are effective against many genera of mosquitoes including Aedes, ${ }^{[2]}$ Anopheles and Mansonia.

The first pyrethroid (fenvalerate) was commercialized in 1978. ${ }^{[3]}$ At present, the class of pyrethroids includes 42 active ingredients, differing in chemical structure or in relative stereoisomer composition

The health implications of burning one mosquito coil is equivalent to the release of the same amount of particulate matter as burning 75 to 137 cigarettes, and emitting formaldehyde equivalent to 51 cigarettes. ${ }^{[4]}$

Pyrethroids have been documented to cause clinical symptoms such as increased urination, jerky movements, ataxia, incoordination, staggering gait, dizziness, altered blood biochemistry, hepatotoxicity, haematoxicity and neurotoxicity. ${ }^{[5]}$

Research also indicates substantial alteration in various organs of different animals exposed to chronic inhalation of mosquito coils smoke. Changes have been reported as early as 7 days. ${ }^{[6]}$

Previous report on histopathological assessments of the kidney tissues of the rats exposed to mosquito coil smoke showed severe multifocal congestion, cystic dilatation in the medulla; proteinaceous casts within ducts, interstitial mononuclear cellular infiltration and widespread fibrosis. ${ }^{[6]}$ It has also been reported that mosquito coil burning leads to increased level of blood urea and creatinine levels. ${ }^{[7]}$

In the present study we intend to do a detailed investigation into the histopathological alteration in kidneys and 


\section{Syed et al; Effects of Masquita Cail Smake an Fidney of Rat.}

hematological-indices (serum urea, creatinine, sodium and potassium)in rats after prolonged and variable exposure to mosquito coil smoke. As substantial data is not available on the effects of mosquito coils containing d-trans allethrin, therefore the present study will provide information of great social impact.

\section{Subjects and Methods}

The present study was carried out on 30 albino rats of Wistar strain of both sexes. The rats were procured from the "Central Animal House" of Government Medical College, Jammu.

The clearance for use of animals was obtained from "Institutional Ethics Committee" of Government Medical College, Jammu

Table 1: Division of animals into 5 groups (A, B, C, D, and E)

\begin{tabular}{|l|l|l|}
\hline Groups & Types & Specimen numbers \\
\hline A & Control group & 6 \\
\hline B & Experimental group & 6 \\
\hline C & Experimental group & 6 \\
\hline D & Experimental group & 6 \\
\hline E & Experimental group & 6 \\
\hline
\end{tabular}

The animals were housed in propylene cages of dimensions $44 \times 28.6 \times 30 \mathrm{~cm} 3$, which were placed in a room of size $10 \times 12$ sq. ft. with cross ventilation and facility of fan, where they were acclimatized for two weeks under standard laboratory condition (12 hour light and 12 hour darkness, temperature at $25 \pm 1^{\circ} \mathrm{C}$ ), with ad libitum access to food and water.

\section{Exposure of the rats}

The animals were exposed to mosquito coil smoke for eight hours a day (average period of time that humans sleeps in a day) using mosquito repellent coil brand containing $0.1 \%$ $\mathrm{w} / \mathrm{w}$ of $\mathrm{d}$-trans allethrin. The mosquito coil was placed at a distance of $30 \mathrm{~cm}$ from the cage

Table 2: Details of exposure of rats to mosquito coil smoke
\begin{tabular}{|l|l|}
\hline Group & Exposure \\
\hline Group A & Unexposed to coil smoke. \\
\hline Group B & Exposed for 4 weeks \\
\hline Group C & Exposed for 6 weeks \\
\hline Group D & Exposed for 8 weeks \\
\hline Group E & Exposed for 10 weeks \\
\hline
\end{tabular}

\section{Collection of Blood}

At the end of exposure period blood was collected from each rat using the retro-orbital procedure.

The tip of the capillary tube was placed at the medial canthus of the eye under the nictitating membrane. As soon as the sinus was punctured, blood entered the tube by capillary action.

$1 \mathrm{ml}$ was collected in a simple vial and sent for kidney function tests, which included, serum creatinine, urea, sodium and potassium levels. Serum urea was estimated by GLDH-urease method. ${ }^{[8]}$ Serum creatinine was estimated by alkaline picrate method. ${ }^{[9]}$ Serum sodium and potassium levels where estimated using respective Accucare Diagnostic Kit (LAB-CARE Diagnostic India Pvt. Ltd., Mumbai ). The results were analysed using one way ANOVA test.

\section{Dissection of the kidneys}

Each rat was placed in a beaker containing chloroform soaked cotton. A lid was placed over the beaker for about 56 minutes to sacrifice the rats. The sacrificed rats were laid supine on the dissecting tray and pinned down at fore- and hind- feet in stretched out position. A midline incision was made in abdominal wall and skin was retracted to open the abdominal cavity. The intestines were displaced to one side to visualise the kidney of opposite sides. The renal vessels and ureters were ligated and cut and the kidneys removed. Tissue of $3 \mathrm{~mm}$ size was cut from kidney by using sharp blade and placed in $10 \%$ formalin solution of, the following composition. ${ }^{[10]}$

I. Formalin : $100 \mathrm{~m}$

II. Tap water : $900 \mathrm{~m}$

III. Sodium chloride : $8.5 \mathrm{gms}$

The tissue samples were embedded into paraffin wax and sectioned into 8 um thick sections using a microtome. Haematoxylin and eosin was used to stain the tissue sections.

Result

Table 3: Levels of serum urea among control and experimental groups (mg/dl)

\begin{tabular}{|c|c|c|c|c|}
\hline Groups & $\begin{array}{l}\text { Mean } \pm \\
\text { SD }\end{array}$ & Range & Comparison & P-value \\
\hline A & $\begin{array}{ll}20.42 & \pm \\
1.68 & \end{array}$ & $18.4-23.1$ & - & - \\
\hline B & $\begin{array}{ll}23.85 & \pm \\
2.36 & \end{array}$ & $19.5-26.5$ & A vs B & 0.011 \\
\hline $\mathrm{C}$ & $\begin{array}{l}26.75 \\
1.00 \\
\end{array}$ & $25.5-28$ & A vs $\mathrm{C}$ & $<0.001$ \\
\hline $\mathrm{D}$ & $\begin{array}{ll}29.58 & \pm \\
1.20 & \end{array}$ & $28-31.5$ & $A$ vs D & $<0.001$ \\
\hline $\mathrm{E}$ & $\begin{array}{ll}35.33 & \pm \\
2.27 & \end{array}$ & $32.9-38.1$ & A vs E & $<0.001$ \\
\hline
\end{tabular}

Table 4: Levels of serum creatinine among control and experimental groups (mg/dl)

\begin{tabular}{|l|l|l|l|c|}
\hline Groups & $\begin{array}{l}\text { Mean } \\
\text { SD }\end{array}$ & Range & Comparison & P-value \\
\hline A & $0.53 \pm 0.23$ & $0.07-0.65$ & - & - \\
\hline B & $1.62 \pm 0.49$ & $0.9-2.3$ & A vs B & 0.028 \\
\hline C & $2.55 \pm 0.37$ & $2-3$ & A vs C & $<0.001$ \\
\hline D & $3.02 \pm 0.25$ & $2.6-3.3$ & A vs D & $<0.001$ \\
\hline E & $2.98 \pm 1.29$ & $0.4-3.8$ & A vs E & $<0.001$ \\
\hline
\end{tabular}

Serum sodium and serum potassium showed no significant change in all experimental groups even after exposure to coil smoke for 10 weeks. [Table 5 and 6]

Table 5: Levels of serum sodium among control and experimental groups (Mmol/L)

\begin{tabular}{|c|c|c|c|c|}
\hline Groups & Mean \pm SD & Range & Comparison & P-value \\
\hline $\mathrm{A}$ & $\begin{array}{ll}149.50 & \pm \\
3.62 & \\
\end{array}$ & $143-153$ & - & - \\
\hline B & $\begin{array}{ll}148.83 & \pm \\
4.17 & \end{array}$ & $143-155$ & A vs B & 0.994 \\
\hline $\mathrm{C}$ & $\begin{array}{ll}153.50 & \pm \\
3.08 & \\
\end{array}$ & $149-157$ & A vs $\mathrm{C}$ & 0.228 \\
\hline $\mathrm{D}$ & $\begin{array}{ll}148.78 \quad \pm \\
4.99\end{array}$ & $141-156$ & A vs D & 0.992 \\
\hline $\mathrm{E}$ & $\begin{array}{ll}148.83 & \pm \\
2.58\end{array}$ & $145-152$ & A vs E & 0.994 \\
\hline
\end{tabular}




\section{Syed et al; Effects of Masquita Cail Smake an Fidney of Rat.}

\section{Haematological Indices}

We found an increased level of Serum urea and creatinine in all experimental groups compared to the control. A statistically significantly increase $(p<0.001)$ was however only observed in Groups C,D, and E which were exposed to mosquito coil smoke for 6,8 and 10 weeks respectively [Tables 3 and 4]

Table 6: Levels of serum potassium among control and experimental groups $(\mathrm{Mmol} / \mathrm{L})$

\begin{tabular}{|c|c|c|c|c|}
\hline Groups & $\begin{array}{l}\text { Mean } \quad \pm \\
\text { SD }\end{array}$ & Range & Comparison & P-value \\
\hline A & $\begin{array}{cc}5.83 & \pm \\
0.33 & \end{array}$ & $5.3-6.2$ & - & - \\
\hline B & $6.02 \pm 0.33$ & $5.5-6.4$ & A vs B & 0.855 \\
\hline $\mathrm{C}$ & $\begin{array}{l}6.23 \\
0.44\end{array}$ & $5.7-7$ & A vs $\mathrm{C}$ & 0.293 \\
\hline $\mathrm{D}$ & $\begin{array}{cc}6.32 & \pm \\
0.46 & \\
\end{array}$ & $5.6-7$ & A vs D & 0.159 \\
\hline $\mathrm{E}$ & $\begin{array}{cc}6.23 & \pm \\
0.47 & \\
\end{array}$ & $5.7-6.9$ & A vs E & 0.293 \\
\hline
\end{tabular}

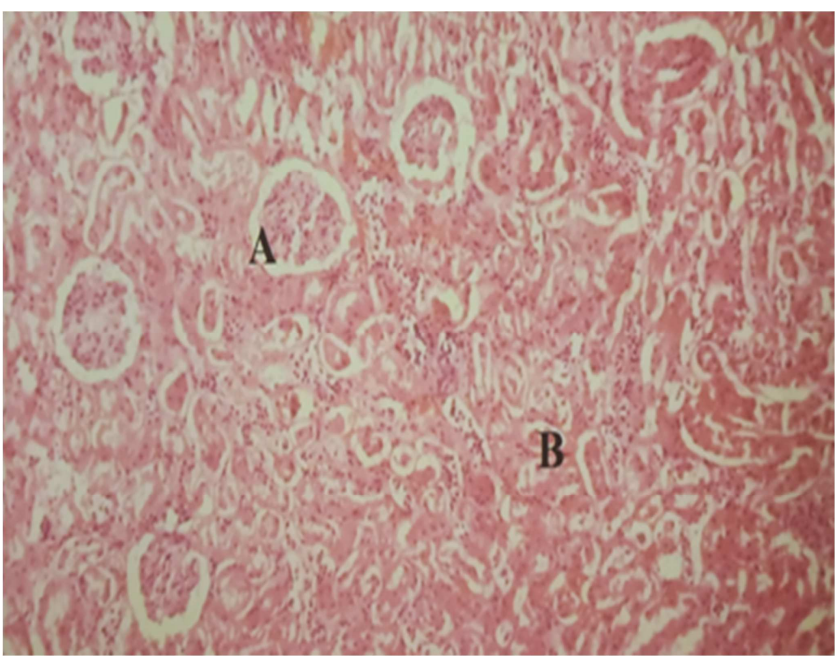

Figure 1: Photomicrography of section of kidney of albino rats of control group showing normal glomeruli (A) and normal tubules (B). (H\&E Stain $100 \mathrm{X})$

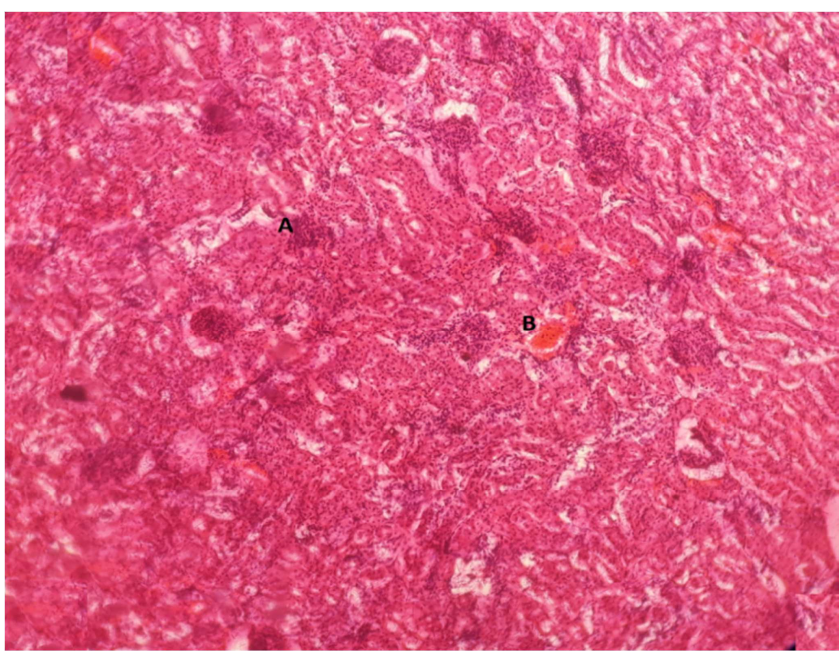

Figure 2: Photomicrography of section of kidney of albino rats after 4 weeks of exposure to mosquito coil smoke showing interstitial chronic inflammation in cortex $\mathbf{A}$ andinterstitial congestion B. (H\&E Stain $100 \mathrm{X})$

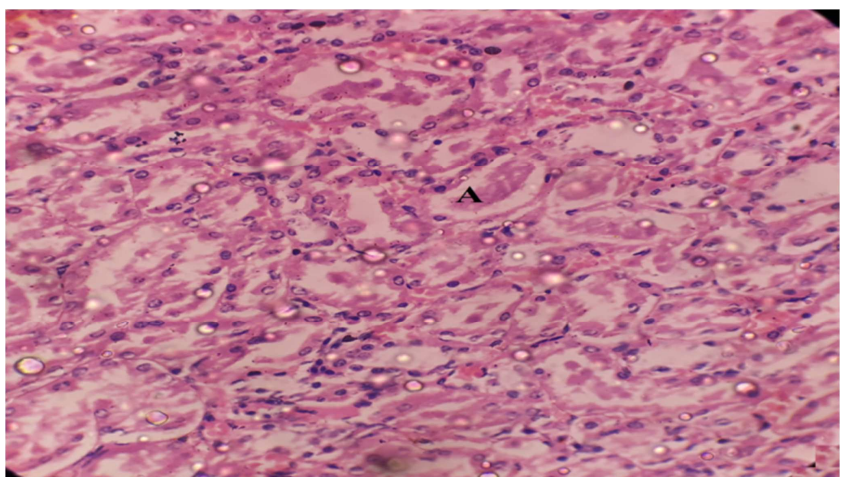

Figure 3: Photomicrography of section of kidney of albino rats after 6 weeks of exposure to mosquito coil smoke showing tubular lumen showing extensive proteinaceous deposits. (H\&E Stain 100X)

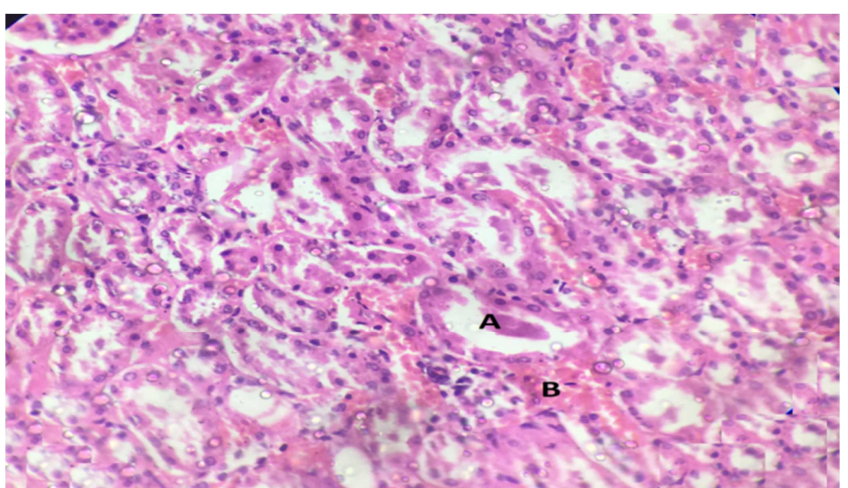

Figure 4: Photomicrography of section of kidney of albino rats after 8 weeks of exposure to mosquito coil smoke showing tubular lumen with focal eosinophilic proteinaceous materia $\mathrm{A}$ and moderate interstitial congestion B. (H\&E Stain 100X)

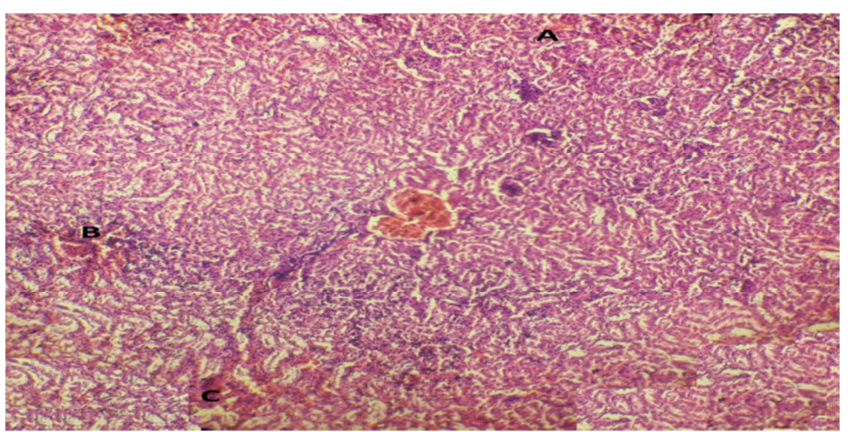

Figure 5: Photomicrography of section of kidney of albino rats after 10weeks of exposure to mosquito coil smoke showing congestion in cortex $A$ and medullary infiltration $B$ and medullary congestion $\mathrm{C}$. (H\&E stain $50 \mathrm{X}$ )

Histopathological findings

\section{Normal Rat Kidney (Group A)}

The proximal convoluted tubules were more numerous in number and were lined by a single layer of low columnar or pyramidal cells which had round nuclei and granular cytoplasm staining deeply with eosin. The cell boundaries of lining epithelium were not clearly defined and the apical surfaces of the cells showed brush border that almost filled the lumen. The nuclei were euchromatic and central in position. The distal convoluted tubules were less numerous in number and they were lined by cuboidal cells that lacked a brush border and contained lightly stained cytoplasm with 


\section{Syed et al; Effects of Masquita Cail Smake an Fidney of Rat.}

central euchromatic nucleus. In the medulla the thick descending and ascending segments of the loops of were lined by similar cells as the distal convoluted tubules. The collecting tubules and ducts of Bellini were lined by cuboidal or columnar epithelium with clear, lightly stained cytoplasm and distinct cell outlines. They had larger lumina and were regular in shape and lacked brush border. The thin segments of loops of Henle were lined by simple squamous epithelium with central bulging nuclei. [Figure 1]

\section{Group B}

The kidneys of the group B rats showed no change in architecture of cortex and medulla. In the cortex, the renal corpuscles appeared normal, with mild congestion of the glomeruli. The interstitium showed mild congestion,focal haemorrhage and focal chronic inflammatory infiltrate. The medulla also showed focal vascular congestion. The tubules appeared normal with normal lining epithelium and empty lumina. The interstitium of the medulla showed mild vascular congestion and haemorrhage with focal chronic inflammatory infiltrate. [Figure 2]

\section{Group C}

The renal corpuscles in the cortex showed moderate congestion of the glomerular tuft of capillaries. Most of the proximal convoluted tubules showed slight dilatation. Their lumina were filled with eosinophilic proteinaceous material. The distal convoluted tubules also appeared dilated with eosinophilic proteinaceous material filling the lumina. The tubules showed swelling of the lining epithelial cells with ballooning degeneration and fragmentation. The interstitium showed moderate congestion and focal chronic inflammatory infiltrate. In the medulla blood vessels were moderately congested. All the tubules showed proteinaceous material in the lumina. The interstitium also showed focal chronic inflammatory infiltrate, vascular congestion and haemorrhage.

\section{Group D}

In the cortex there was marked congestion of the glomerular capillaries. The proximal convoluted tubules appeared dilated with eosinophilic proteinaceous material in the lumina of approximately half of the tubules. Half of the tubules were normal appearing with empty lumina. The distal convoluted tubules also showed dilatation with eosinophilic material filling some lumina only, the rest of the tubules were normal appearing with empty lumina.

The interstitium showed focal congestion, haemorrhage with focal chronic inflammatory cell collection in the interstitium. The medulla showed focal vascular congestion. Half of the tubules in the medulla were filled with eosinophilic hyaline material and the other half of tubules appeared normal. The interstitium of the medulla also showed focal vascular congestion, haemorrhage and chronic inflammatory infiltrate.[Figure 4]

\section{Group E}

In the cortex there was marked congestion and infiltration of the glomerular capillaries. The interstitium also showed signs of marked congestion and infiltration.[Figure 5]

Table 6: Light microscopic changes in kidneys exposed to mosquito coil smoke.

\begin{tabular}{|c|c|c|c|c|c|}
\hline CHANGES & Group A & Group B & Group C & Group D & Group E \\
\hline \multicolumn{6}{|l|}{ 1. Glomeruli } \\
\hline & Normal glomeruli & Mild congestion & Moderate congestion & Marked congestion & Marked congestion \\
\hline \multicolumn{6}{|l|}{ 2.Interstitium } \\
\hline a. Congestion & No & mild & Moderate & Focal & Marked \\
\hline b. Infiltration & No & $\begin{array}{l}\text { Chronic inflammatory } \\
\text { cells }\end{array}$ & $\begin{array}{l}\text { Focal chronic } \\
\text { inflammatory cells }\end{array}$ & $\begin{array}{l}\text { Chronic inflammatory } \\
\text { cells }\end{array}$ & Marked \\
\hline c. Haemorrhage & No & Focal Haemorrhage & Haemorrhage present & Focal Haemorrhage & Haemorrhage \\
\hline \multicolumn{6}{|l|}{ 3. Tubules } \\
\hline a. Casts & Absent & Absent & Present & Present & Absent \\
\hline $\begin{array}{l}\text { b. Ballooning } \\
\text { degeneration } \\
\text { epithelium }\end{array}$ & Absent & Absent & Present & Absent & Absent \\
\hline
\end{tabular}

\section{Discussion}

Agarwal et al. ${ }^{[7]}$ conducted a study on 15 rats for a period of 4 weeks. They demonstrated an increase in serum urea levels from $16.03 \pm 1.33 \mathrm{mg} / \mathrm{dl}$ (control group) to $18.16 \pm 0.42 \mathrm{mg} / \mathrm{dl}$ (4 weeks exposure) and the serum creatinine levels from $0.48 \pm 0.03 \mathrm{mg} / \mathrm{dl}$ to $0.63 \pm 0.04 \mathrm{mg} / \mathrm{dl}$ (4 weeks exposure). The results demonstrated a significant increase in both the values, which is in line with results of the present study. Significant increase in the serum creatinine levels $(p<0.05)$ was also reported by Ugwu et al. ${ }^{[1]}$ and Ogbonnia et al. ${ }^{[12]}$ in experimental groups of rats exposed to different brands of mosquito coils for a period of 31 days, which supports our result of increase in serum creatinine in group B i.e. 4 weeks of exposure. Ibiam et al. ${ }^{[13]}$ conducted a study on rats using two different brands of mosquito coil for a period of 4 weeks. Their results indicated a significant increase in serum creatinine in both exposed groups, which is again similar to our finding in the present study for Group B rats. According to a study conducted by Okine et al. ${ }^{[14]}$ chronic exposure of mosquito coil smoke for 6 weeks showed no significant increase in serum creatinine levels. The study is in discordance to our study. Siddique et al. ${ }^{[15]}$ in their study on Wistar rats exposed for 4 weeks reported haemorrhage, congestion of blood vessels, cellular infiltration and fibrosis in the interstitium of kidneys. These findings are in concordance with the results obtained in our study for group B that was exposed for a period of 4 weeks. Further Agarwal et al. ${ }^{[16]}$ also reported marked symptoms of renal tissue impairment in rats exposed to mosquito coil smoke for 4 weeks, which included interstitial infiltration that was in favour of our study. They also reported glomerular degeneration and tubular degeneration that was also observed in our study. Idowu et al. ${ }^{[17]}$ reported no 
morphological changes in exposed rats till 8 weeks when they reported mild interstitial congestion. Full congestion was reported at around 16 weeks of exposure. The study is in discordance with our study as we observed congestion as early as 4 weeks and maximum congestion was reported in the exposed animals at 10 weeks Ayorinde et al. ${ }^{[18]}$ reported no change in the histology of kidneys. of exposed animals and the same was also observed by Okine et al. ${ }^{[14]}$ which is in discordance with our study.

Urea is formed by deamination of amino acids in the liver, and then it is transported by blood to the kidneys where it is excreted with urine. ${ }^{[19]}$ Elevation of serum urea observed in the present study in response to pesticides exposure may be explained by: 1) impairment in its synthesis as a result of impaired hepatic function, 2) disturbance in protein metabolism and 3) decrease in the filtration rate of the kidney. ${ }^{[20]}$

Creatinine is a waste product that is normally filtered from the blood and excreted with urine. Increase in creatinine level in response to pesticide exposure indicates renal disease and may be a result of impaired glomerular function. ${ }^{[22,23]}$

\section{Conclusion}

The coil smoke can be toxic for humans as well and general masses should be made aware about the possible hazards of the over-use of mosquito coils. Adequate measures should be taken to ensure minimal exposure to coil smoke during domestic use.

\section{References}

1. National vector borne disease control programme, annual report 2016-2017.

2. Lukwa $\mathrm{N}$ and Chandiwana SK. Efficacy of Mosquito Coil Containing $0.3 \%$ and $0.4 \%$ Pyrethrin Against An. Gambiae Sensu Lato Mosquitoes. Cent Afr J Med.1998;44(4):104-107.

3. WHO Pesticide Evaluation Scheme, World Health Organization. Chemical Safety Team. Safety of Pyrethroids for Public Health Use. Geneva: World Health Organisation, 2005.

4. Chen SC, Wong RH, Shiu LJ et al. Exposure To Mosquito Coil Smoke May be a Risk Factor for Lung Cancer in Taiwan. J Epidemiol.2008;18(1):19-25.

5. Saka WA, Akhigbe RE, Azeez OM et al.Effects of Pyrethroid Insecticide Exposure on Haematological and Haemostatic Profiles in Rats. Pak J Biol Sci.2011;14(22):1024-1027.

6. Garba SH, Adelaiye AB, Mshelia LY. Histopathological and Biochemical Changes in Rats Kidney Following Exposure to a
Pyrethroid Based Mosquito Coil. J Appl Sci Res.2007; 3(12): 1788-1793.

7. Agarwal A, Jabbar M, Kumari R. Mosquito Coil Smoke Induced Serum Biochemical Alteration in Albino Rats. Int J Pharm Bio Sci.2014;5(2):920-923.

8. Young DS. Effects of drugs on clinical laboratory tests. AACC press; 2000.

9. Henry R, Cannon D, Winkelman W. Clinical Chemistry Principals and Techniques. 11th, editor. New York: Happer and Row Publishers. 1974.

10. Drury RAB, Wallington EA. General Staining Procedures, Carleton's Histological Techniques, 5th edition. New York: Oxford University Press; 1980. p 125-150.

11. Ugwu, Ogbonnia O, Ibiam et al. Protective Effect of Gongronema Latifolium Leaf Extract on Rambo and Cork Mosquito Coil Smoke-Induced Liver Toxicity In Albino Rats. Asian Acad Res J Multidisciplinary.2015;29(1):2319-2801.

12. Ogbonnia UO, UduIA,Okorocha EA et al. The Effect of Pyrethroid-based Insecticides (Rambo and Raid mosquitocoil) Smoke on Some Biochemical Indices in Albino Rats and the Protective Effect of Aqueous Extract of Piper guineense. Middle East J Scientific Res.2016;24(2):306-313.

13. Ibiam UA, Okechukwu OU, Nzubechukwu E et al. Hepatotoxicity of Rambo and Cork Mosquito-Coil Smoke and the Protective Effects of G. Latifolium Leaf Extract. J Nat Sci.2015; 5(1):13-18.

14. Okine LKN, Nyarko AK, Armah GE et al. Adverse Effects of Mosquito Coil Smoke on Lung, Liver and Certain Drug Metabolizing Enzymes in Male Wistar Albino Rats. Ghana Med J.2004; 38(3): 89-95.

15. Siddique N, Nazir S, Jabeen R. Mosquito Coil Smoke Inhalation Effects on Interstitium of Kidney of Albino Rats. Pak J Med Health Sci.2015;2(9):672-675.

16. Agarwal A, Yadav AK, Singh R. Ameliorating Effects Of Garlic Oil Against Mosquito Coil Smoke Induced Histopathological Changes In Rat Kidney. Int J Pharm Bio Sci.2013;4(2):11121116.

17. Idowu ET, Aimufua OJ, Ejovwoke YO et al. Toxicological Effects of Prolonged and Intense use of Mosquito Coil Emission in Rats and its Implications on Malaria Control. Int J Trop Biol.2013; 61 (3): 1463-1473.

18. Ayorinde AF, Oboh BO, Otubanjo OA et al. Some Toxicological Effects of a Mosquito Repellent in Lagos State, Nigeria. Res J Environ Toxicol.2014;8(1);46-52.

19. Harvey RA, Ferrier DR. Lippincott's Illustrated Re-views: Biochemistry. 5th ed. Philadelphia, PA, USA: Lippincott Williams \& Wilkins, a Wolters Kluwer business; 2011.

20. Khan DA, Bhatti MM, Khan FA et al. Adverse effects of pesticides residues on bio-chemical markers in Pakistani tobacco farmers. Int J Clin Exp Med.2008; 1: 274-282

21. Khan AL, Ahmad L, Khan MZ. Hemato-biochemical changes induced by pyrethroid insecticides in avian, fish and mammalian species. Int J Agric Biol.2012; 14: 834-842.

22. Gowda S, Desai PB, Kulkarni SS et al. Markers of renal function tests. N Am J Med Sci.2010; 2 (4): 170-173.

Copyright: ( $)$ the author(s), publisher. Academia Anatomica International is an Official Publication of "Society for Health Care \& Research Development". It is an open-access article distributed under the terms of the Creative Commons Attribution Non-Commercial License, which permits unrestricted non-commercial use, distribution, and reproduction in any medium, provided the original work is properly cited.

How to cite this article: Syed M, Tousia S, Balowria KS, Jabeen N, Faruqi NA, Beg A. Haematological and Histopathological Effects of Mosquito Coil Smoke on Kidney-An Experimental study on Albino Rat. Acad. Anat. Int. 2019;5(1):49-53.

DOI: dx.doi.org/10.21276/aanat.2019.5.1.11

Source of Support: Nil, Conflict of Interest: None declared. 